\title{
A Revision of the Genus Lomanella Pocock and its Implications for Family Level Classification in the Travunioidea (Arachnida: Opiliones: Triaenonychidae)
}

\author{
GLENN S. HUNT ${ }^{1}$ \& JOHN L. HICKMAN ${ }^{2}$ \\ ${ }^{1}$ Australian Museum, \\ PO Box A285, Sydney South, NSW 2000, Australia \\ ${ }^{2}$ Honorary Research Associate, Department of Zoology, \\ University of Tasmania, Box 252C, GPO Hobart, Tas. 7001, Australia
}

\begin{abstract}
Genus Lomanella Pocock, 1903 is redescribed for type species, L. raniceps Pocock, and 18 other species. One new combination is established: L. inermis (Callihamus) (Roewer, 1931). Four species groups are recognised on morphological grounds for the six previously described species and 13 new species: L. raniceps species group comprises L. raniceps, L. atrolutea Roewer, 1915, L. inermis (Roewer, 1931), L. kallista Forster, 1949, L. ambulatorio n.sp., L. balooki n.sp., and $L$. promontorium n.sp.; $L$. insolentia species group comprises $L$. insolentia n.sp., $L$. revelata n.sp., $L$. troglophilia $n$.sp., and $L$. alata $n$.sp.; L. exigua species group comprises $L$. exigua V.V. Hickman, 1958, L. parva Forster, 1955, L. browni n.sp., L. thereseae n.sp., L. troglodytes n.sp., L. quasiparva n.sp., and $L$. blacki n.sp.; and the $L$. peltonychium species group comprises a single species, L. peltonychium n.sp. A lectotype male and paralectotype female are designated for $L$. atrolutea. A key to males is provided. Within the genus, tarsal claws of legs III and IV range from a simple trifurcating claw typical of many triaenonychids, to a complex multiply-branched peltonychium. There is also simplification of penis structure within species of Lomanella. The significance of both claw and penis structure to family level classification in the Travunioidea is discussed and it is shown that a subfamily classification of the Triaenonychidae based on claw morphology is difficult to sustain. Three species are known to inhabit caves including a second totally eyeless triaenonychid. The penis of Nucina silvestris V.V. Hickman is redescribed as it shows reduction in plates parallelling that in some Lomanella spp.
\end{abstract}

HunT, G.S. \& J.L. HickMAN, 1993. A revision of the genus Lomanella Pocock and its implications for family level classification in the Travunioidea (Arachnida: Opiliones: Triaenonychidae). Records of the Australian Museum 45(1): 81-119. 